\title{
Patterns of diversity in pigeonpea (Cajanus cajan (L.) Millsp.) germplasm collected from different elevations in Kenya
}

\author{
Hari D. Upadhyaya $\cdot$ K. N. Reddy $\cdot$ C. L. L. Gowda • \\ S. N. Silim
}

Received: 28 September 2006 / Accepted: 13 December 2006/ Published online: 6 March 2007

(C) Springer Science+Business Media B.V. 2007

\begin{abstract}
Pigeonpea germplasm accessions collected from low $(<500 \mathrm{~m})$, medium (501$1000 \mathrm{~m})$, high (1001-1500 m) and very high elevation zones $(>1500 \mathrm{~m})$ of Kenya were evaluated for 15 agronomic traits and seed protein content at ICRISAT, Patancheru, India. There were significant differences $(P<0.001)$ among elevation zones for the number of primary and secondary branches, days to $75 \%$ maturity, pod length, seeds per pod, 100-seed weight and seed yield. Mean values indicated that the accessions from low elevation zone were significantly different from those collected in higher elevation zones for early flowering and maturity, number of primary branches, pod length, number of pods per plant, seeds per pod, 100-seed weight, seed yield and harvest index. None of the accessions collected in Kenya belonged to extra early ( $<80$ days to $50 \%$ flowering) and early (80-100 days to $50 \%$ flowering) maturity groups, as defined by time to flowering at Patancheru,
\end{abstract}

H. D. Upadhyaya $(\bowtie) \cdot$ K. N. Reddy .

C. L. L. Gowda

Genetic Resources, Global Theme on Crop

Improvement, International Crops Research Institute

for the Semi-Arid Tropics (ICRISAT), Patancheru,

Andhra Pradesh 502 324, India

e-mail: H.Upadhyaya@CGIAR.ORG

S. N. Silim

ICRISAT-Nairobi (Regional hub ESA), PO Box

39063, Nairobi, Kenya
India. Mean diversity index based on all characters indicated that accessions from the low elevation zone are more diverse than those from the higher elevation zones. Frequency distribution for trait extremes indicated that the accessions from the low elevation zone were early to flower and mature, short statured, produced more primary and secondary branches with high pod bearing length, long pods, more pods per plant, more seeds per pod, a high seed yield and harvest index. Accessions from the very high elevation zone were late flowering, with a large number of tertiary branches, large seeds and a high shelling percentage and could be a source for cold tolerance and the breeding of vegetable types. Results suggest that the elevation of collection sites is therefore a very important determinant of variation patterns of pigeonpea in Kenya.

Keywords Agronomic traits - Cajanus cajan . Collection sites · Diversity · Elevation .

Pigeonpea

\section{Introduction}

Pigeonpea (Cajanus cajan (L.) Millsp.) is an important legume of the tropics and subtropics. Because of multiple uses (source of food, fodder and fuel wood; material for thatching and fencing, and for soil improvement and windbreaks), it 
plays an important role in subsistence agriculture. Pigeonpea is grown as a field crop as well as backyard crop in more than 80 countries. During 2005 , pigeonpea as a field crop was grown on an estimated 4.6 million ha, with a production of 3.5 million $t$ and an average productivity of $0.90 \mathrm{t}$ $\mathrm{ha}^{-1}$. India has the largest area under pigeonpea (3.3 m ha) followed by Myanmar (0.58 m ha), Kenya (0.15 m ha), Malawi (0.12 m ha), Uganda (0.08 m ha), Tanzania (0.07 m ha), Nepal (0.03 m ha) and Dominican Republic (0.01 m ha) (FAO 2005). Since, in most pigeonpea growing countries pigeonpea is grown to a considerable extent in kitchen gardens, field bunds, in intercropped conditions, FAO estimates are considered to have not captured the entire extent of pigeonpea production.

The evolution of pigeonpea through natural and human selection in diverse elevation zones and under different cropping systems has resulted in a wide variety of locally adapted landraces. These landraces have evolved over years to fit into local cropping patterns and diverse end uses and represent a wide range of patterns of crop diversity. The knowledge of patterns of genetic variation of a crop species in any given region or country is very important for planning future germplasm collection missions and for efficient utilization of collected germplasm in crop improvement programs (Hayward and Breese 1993). Kenya, which lies between $4^{\circ} \mathrm{S}$ and $4^{\circ} \mathrm{N}$ on Eastern Africa's east coast is the most important pigeonpea growing country in Africa. More than half of the Kenya's land resources lie above 1,500 m.a.s.l. (Remanandan et al. 1982). The range of elevation of collection sites of accessions conserved in the ICRISAT genebank varies from 60 to $2000 \mathrm{~m}$, within a narrow range of latitude, making temperature a major determinant of diversity patterns in Kenyan pigeonpea. This paper assesses the pattern of diversity distribution in relation to the elevation of pigeonpea germplasm collecting sites in Kenya.

\section{Materials and methods}

The R S Paroda genebank at ICRISAT, Patancheru, India has the global responsibility for collecting and conserving pigeonpea germplasm. Two germplasm collection missions were undertaken in Kenya in 1976 and 1982, which collected 63 and 247 pigeonpea samples, respectively (van der Maesen 1976; Remanandan et al. 1982). Collection was done over a wide range of elevation (60 m-2000 m.a.s.l.). Collection sites were classified as low $(<500 \mathrm{~m})$, medium $(501-1000 \mathrm{~m})$, high $(1001-1500 \mathrm{~m})$ and very high $(>1500 \mathrm{~m})$ elevations. This classification of the Kenyan collection resulted in 42 accessions $(13.6 \%)$ from the low elevation zone, $68(21.9 \%)$ from the medium elevation zone, $177(57.1 \%)$ from the high elevation zone and $23(7.4 \%)$ from very high elevation zone (Fig. 1).

Accessions were evaluated for 16 quantitative characters in different years at ICRISAT Center, Patancheru, A.P. India $\left(17^{\circ} 25^{\prime} \mathrm{N}\right.$ latitude, $78^{\circ}$ $00^{\prime}$ E longitude and 545 m.a.s.l.) in vertisols during rainy season. Accessions were sown in three rows of $4 \mathrm{~m}$ long, with a spacing of $50 \mathrm{~cm}$ between plants and $75 \mathrm{~cm}$ between rows. The crop was fertilized with $20 \mathrm{~kg} \mathrm{~N}$ and $40 \mathrm{~kg} \mathrm{P}_{2} \mathrm{O}_{5} \mathrm{ha}^{-1}$ as basal dose, managed by recommended cultural and plant protection practices, including supplementary irrigation if required. Observations were recorded as mean of three representative plants from the middle row for plant height, number of primary, secondary and tertiary branches, number of racemes, pod bearing length, pod length, number of pods per plant, seeds per pod, 100seed weight, shelling percentage, seed yield per plant and harvest index following the Descriptors for Pigeonpea (IBPGR and ICRISAT 1993). Observations on days to $50 \%$ flowering and days to $75 \%$ maturity were recorded on plot basis. Seed protein content was estimated with Technicon Autoanalyser (Singh and Jambunathan 1980). The data were analyzed using GENSTAT 6.1. The range, mean and variance for all traits were calculated for each of the four elevation zones. The differences between means of the different elevation zones were compared using the Newman-Keuls procedure for all traits (Newman 1939; Keuls 1952). The homogeneity of variances among the elevation zones was tested using Levene's test (Levene 1960), and phenotypic diversity was estimated by the Shannon and Weaver diversity index $\left(\mathrm{H}^{\prime}\right)$ (Shannon and 
Fig. 1 Map showing pigeonpea germplasm collection sites at different elevations in Kenya

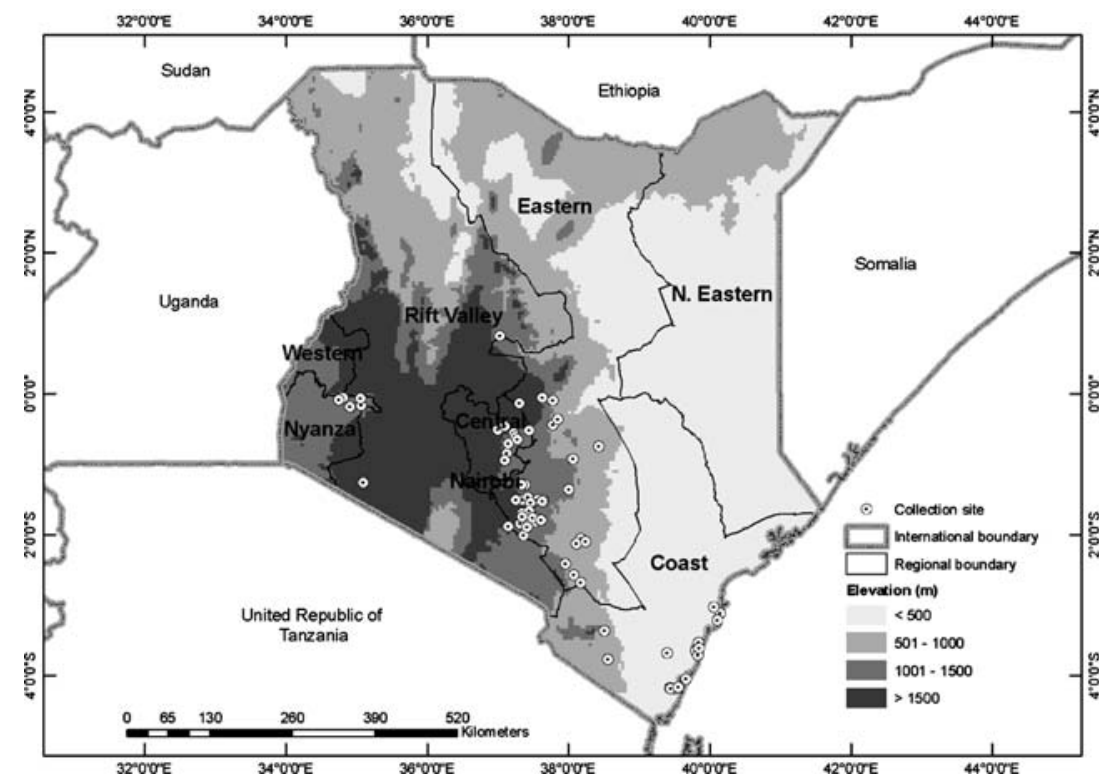

Weaver 1949). The index was estimated for each of the16 traits within each elevation zone. The frequency distribution of accessions for each extreme group within each character was calculated to identify the trait specific germplasm that is available at different elevations of Kenya.

\section{Results and discussion}

Kenya has a bimodal rainfall distribution with the short rains falling during October-November and the long rains during March-May (Remanandan et al. 1982). In Kenya, pigeonpea is usually sown during short rains, with major vegetative growth occuring during the long rains. Flowering commences after long rains followed by pod development during the cold dry months of June-July and the crop matures in the warm, dry months of August-September. Traditional types grown in Kenya are long duration (10 months), indeterminate types that are adapted to such a bimodal rainfall pattern (Remanandan et al. 1991). Because of varying climate, particularly, the minimum and maximum temperature differences in the four elevation zones, pigeonpea germplasm from Kenya is expected to vary considerably for many characters.

Variances among the elevation zones differed significantly $(P<0.001)$ for number of primary and secondary branches, days to $75 \%$ maturity, pod length, seeds per pod, 100-seed weight and seed yield (Table 1). Variances for days to $50 \%$ flowering, days to $75 \%$ maturity, plant height, pod length, seeds per pod, and seed yield per plant decreased with the increase in elevation of collection sites. Variances for number of secondary branches, number of racemes, pod bearing length and number of pods was highest in accessions from medium elevation zone.

The range and mean values for all characters are given in Table 2. The range among accessions was greatest in low elevation zone for number of primary branches, seeds per pod and seed yield per plant, in the medium elevation zone for days to $75 \%$ maturity, number of secondary branches, number of racemes, pod-bearing length, pod length and harvest index, and in the high elevation zone for days to $50 \%$ flowering, plant height, number of primary branches, number of tertiary branches, number of pods per plant, 100-seed weight, shelling percentage and seed protein content. Interestingly, the variation in the very high elevation zone was the lowest for all traits, except for seed protein content, which may be attributed to the natural selection and the intensive selection practiced by farmers at higher elevations.

The Newman-Keuls test of significance for mean values indicated that the accessions from 
Table 1 Variances for various characters of pigeonpea germplasm collected from different elevations of Kenya

\begin{tabular}{|c|c|c|c|c|c|c|}
\hline \multirow[t]{2}{*}{ Character } & \multicolumn{6}{|c|}{ Elevation (m.a.s.l.) } \\
\hline & Low $(<500)$ & $\begin{array}{l}\text { Medium } \\
(500-1000)\end{array}$ & $\begin{array}{l}\text { High } \\
(1000-1500)\end{array}$ & $\begin{array}{l}\text { Very high } \\
(>1500)\end{array}$ & $F$ value $^{\mathrm{a}}$ & Probability \\
\hline Days to $50 \%$ flowering & 561.81 & 353.77 & 329.67 & 228.51 & 1.86 & 0.1370 \\
\hline Days to $75 \%$ maturity & 1034.04 & 380.04 & 337.86 & 131.08 & 8.59 & $<0.0001$ \\
\hline Plant height $(\mathrm{cm})$ & 2451.92 & 1577.94 & 1581.33 & 1329.35 & 2.56 & 0.0550 \\
\hline $\begin{array}{l}\text { Primary branches per plant } \\
\text { (no.) }\end{array}$ & 20.22 & 9.94 & 10.52 & 10.39 & 2.92 & 0.0340 \\
\hline Secondary branches per plant (no.) & 84.74 & 96.49 & 48.45 & 72.06 & 2.69 & 0.0470 \\
\hline $\begin{array}{l}\text { Tertiary branches per plant } \\
\text { (no.) }\end{array}$ & 12.46 & 20.72 & 31.89 & 15.17 & 0.32 & 0.8110 \\
\hline Racemes per plant (no.) & 1478.13 & 2063.21 & 877.30 & 135.03 & 1.56 & 0.2000 \\
\hline Pod bearing length $(\mathrm{cm})$ & 118.12 & 276.77 & 170.22 & 17.95 & 2.26 & 0.0811 \\
\hline Pod length $(\mathrm{cm})$ & 2.07 & 1.10 & 0.79 & 0.74 & 6.70 & 0.0002 \\
\hline Pods per plant (no.) & 6334.28 & 6977.28 & 4469.68 & 475.95 & 0.77 & 0.5111 \\
\hline Seeds per pod (no.) & 0.72 & 0.30 & 0.25 & 0.14 & 8.70 & $<0.0001$ \\
\hline 100 seed weight $(\mathrm{g})$ & 3.77 & 7.00 & 10.67 & 7.53 & 3.39 & 0.0184 \\
\hline Shelling percentage & 127.27 & 127.51 & 126.72 & 169.69 & 0.22 & 0.8830 \\
\hline Seed yield per plant $(\mathrm{g})$ & 1008.38 & 358.72 & 250.98 & 89.34 & 7.72 & $<0.0001$ \\
\hline Harvest index (\%) & 33.49 & 38.01 & 28.24 & 10.96 & 1.05 & 0.3699 \\
\hline Seed protein content ( $\%)$ & 2.10 & 2.35 & 2.08 & 3.15 & 1.55 & 0.2031 \\
\hline
\end{tabular}

a Variance homogeneity tested by Leven's test

low elevation differed significantly from those of other elevation zones for a number of traits (early flowering and maturity, primary branches number, pod length, number of pods, seeds per pod, seed yield and harvest index) (Table 2). Because of their early maturity, accessions from the low elevation produced pods with smaller seeds. As per the standard maturity classification followed at ICRISAT, none of the accessions from Kenya belong to extra early ( $<80$ days to $50 \%$ flowering) and early (80-100 days to $50 \%$ flowering) maturity groups, when assessed at ICRISAT Patancheru. Only 12 accessions belong to the medium maturity group (100-130 days to 50\% flowering) and 298 accessions to late maturity group (>130 days to $50 \%$ flowering) (ICRISAT 1978). Mean values for pod bearing length decreased with the increase in elevation, with accessions from the very high elevations having smallest pod bearing length (Table 2). Accessions from the low and medium elevations produced a significantly higher number of racemes than those from the high and very high elevations. Accessions from the medium, high and very high elevations were generally similar for number of primary branches, pod length, number of pods, seeds per pod, 100seed weight and seed yield. The increased seed weight of pigeonpea accessions from higher elevations, where late maturing pigeonpeas are common, (Table 4) may be attributed to the prevailing low temperatures and consequently longer seed filling period similar to pearl millet (Ong and Monteith 1985). The elevation of origin has no significant effect on seed protein content.

Shannon-Weaver diversity index $\left(\mathrm{H}^{\prime}\right)$ was estimated to compare phenotypic diversity among the accessions from different elevation zones based on all characters (Table 3). A low $\mathrm{H}^{\prime}$ value indicates low diversity and unbalanced frequency classes. The $\mathrm{H}^{\prime}$ estimates indicated considerable differences in diversity for all characters among accessions collected in different elevation zones. Mean diversity over all characters indicates relatively more diverse pigeonpea accessions in the low elevation zone than those from all other zones, which can be attributed to the prevailing optimum climatic conditions for pigeonpea growth in the low elevation zone. Averaged over the elevation zones, $\mathrm{H}^{\prime}$ values ranged from $0.42 \pm 0.05$ (number of pods) to $0.60 \pm 0.01$ (pod length). Diversity was greater in accessions from the low elevation zone for number of racemes, pod bearing length, number of pods per plant and harvest index; in the medium elevation zone for 


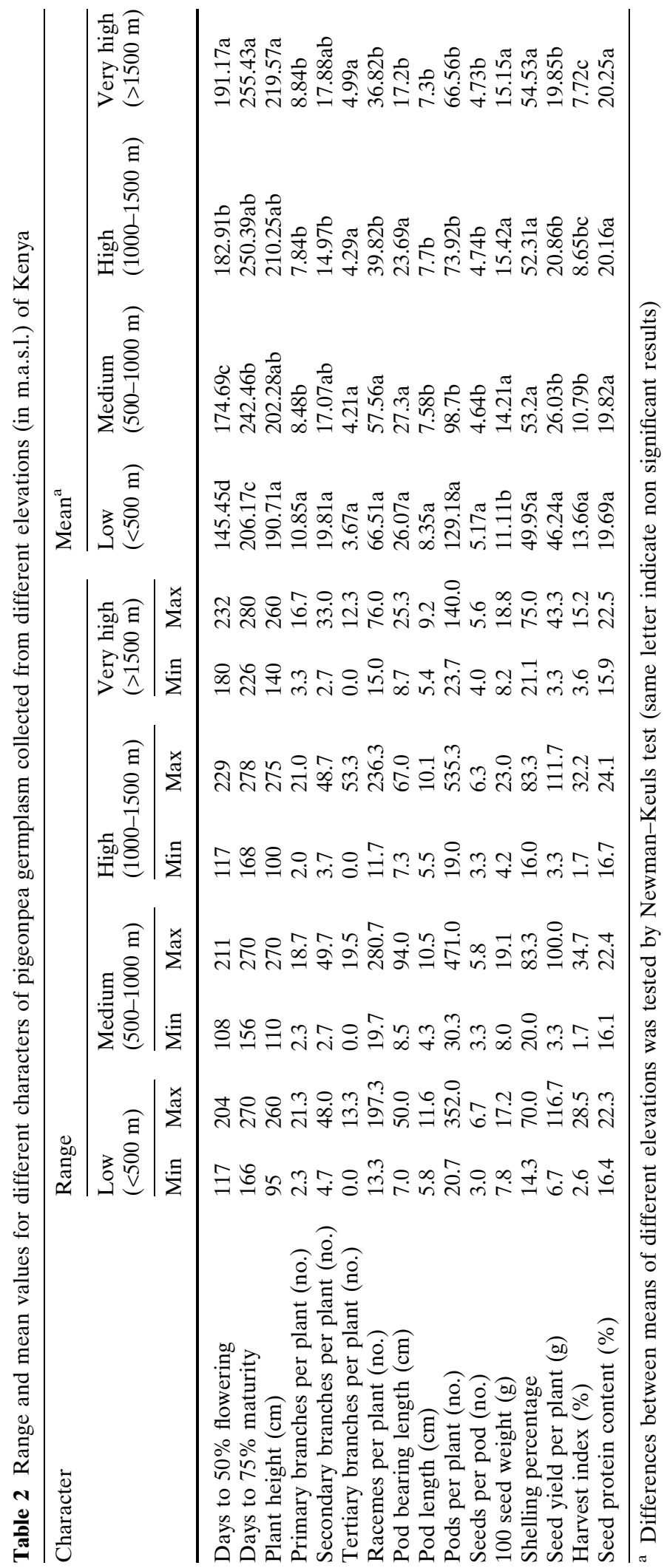


Table 3 Shannon-Weaver diversity indices for various characters of pigeonpea germplasm collected from different elevations of Kenya

\begin{tabular}{|c|c|c|c|c|c|}
\hline \multirow[t]{2}{*}{ Character } & \multicolumn{5}{|c|}{ Elevation (m.a.s.1.) } \\
\hline & $\begin{array}{l}\text { Low } \\
(<500)\end{array}$ & $\begin{array}{l}\text { Medium } \\
(500-1000)\end{array}$ & $\begin{array}{l}\text { High } \\
(1000-1500)\end{array}$ & $\begin{array}{l}\text { Very high } \\
(>1500)\end{array}$ & Mean \\
\hline Days to $50 \%$ flowering & 0.49 & 0.61 & 0.62 & 0.36 & $0.52 \pm 0.06$ \\
\hline Days to $75 \%$ maturity & 0.50 & 0.52 & 0.55 & 0.36 & $0.48 \pm 0.04$ \\
\hline Plant height $(\mathrm{cm})$ & 0.51 & 0.60 & 0.58 & 0.49 & $0.54 \pm 0.03$ \\
\hline Primary branches per plant (no.) & 0.60 & 0.59 & 0.59 & 0.56 & $0.58 \pm 0.01$ \\
\hline Secondary branches per plant (no.) & 0.56 & 0.55 & 0.58 & 0.56 & $0.56 \pm 0.01$ \\
\hline Tertiary branches per plant (no.) & 0.46 & 0.46 & 0.37 & 0.51 & $0.45 \pm 0.03$ \\
\hline Racemes per plant (no.) & 0.56 & 0.37 & 0.37 & 0.46 & $0.44 \pm 0.05$ \\
\hline Pod bearing length $(\mathrm{cm})$ & 0.56 & 0.44 & 0.50 & 0.56 & $0.52 \pm 0.03$ \\
\hline Pod length $(\mathrm{cm})$ & 0.57 & 0.60 & 0.62 & 0.61 & $0.60 \pm 0.01$ \\
\hline Pods per plant (no.) & 0.54 & 0.34 & 0.34 & 0.46 & $0.42 \pm 0.05$ \\
\hline Seeds per pod (no.) & 0.59 & 0.56 & 0.62 & 0.57 & $0.59 \pm 0.01$ \\
\hline 100 seed weight $(\mathrm{g})$ & 0.55 & 0.60 & 0.63 & 0.52 & $0.58 \pm 0.03$ \\
\hline Shelling percentage & 0.58 & 0.59 & 0.59 & 0.60 & $0.59 \pm 0.00$ \\
\hline Seed yield per plant (g) & 0.50 & 0.47 & 0.45 & 0.54 & $0.49 \pm 0.02$ \\
\hline Harvest index (\%) & 0.59 & 0.56 & 0.52 & 0.42 & $0.53 \pm 0.04$ \\
\hline Seed protein content (\%) & 0.58 & 0.61 & 0.62 & 0.55 & $0.59 \pm 0.02$ \\
\hline Mean & $0.55 \pm 0.001$ & $0.53 \pm 0.020$ & $0.53 \pm 0.030$ & $0.51 \pm 0.020$ & \\
\hline
\end{tabular}

plant height; in the high elevation zone for days to $50 \%$ flowering, days to $75 \%$ maturity, pod length, seeds per pod, 100-seed weight and seed protein content; and in the very high elevation zone for pod bearing length, shelling percentage and seed yield per plant.

Considering the wide variation for different characters, accessions were grouped based on the extreme values of each character. For example, in case of days to $50 \%$ flowering, accessions that flowered in $<130$ days were considered as early and those flowered in $>160$ days as late flowering with reference to the Kenyan collection. This type of classification resulted in identification of the best sources of trait-specific germplasm for use in pigeonpea improvement. The low elevation zone was a more promising source of early flowering and early maturing accessions than all other elevation zones (Table 4). The frequency of early flowering and early maturing accessions decreased with the increase in elevation. None of the accessions from very high elevation zone were early flowering or maturing. Kenya lies on the equator, with day-lengths close to $12 \mathrm{~h}$ throughout the year (Remanandan et al. 1991). Pigeonpea is a quantitative short day plant, and most cultivars of all maturity groups flower readily in day-lengths of
11-11.50 h (Gooding 1962; Spence and Williams 1972). Thus no effect of photoperiod on flowering would be expected for pigeonpea in the country. However, the range of elevation in the country substantially modifies temperatures and consequently the rate of heat unit accumulation. Gupta et al. (1991) reported the relationships between latitude, altitude and temperature and observed a decrease of $1^{\circ} \mathrm{C}$ of mean annual temperature with the increase of $150 \mathrm{~m}$ in elevation. Therefore, pigeonpea germplasm adapted to high altitudes of Kenya could be a good source for cold tolerance. Averaged over 30 years, mean minimum temperature of all collection sites decreased from $22.8^{\circ} \mathrm{C}$ to $15.7^{\circ} \mathrm{C}$ and mean maximum temperature from $32.4^{\circ} \mathrm{C}$ to $27.9^{\circ} \mathrm{C}$, with increasing elevation. Thus all but the low elevation zone have sub optimum temperatures for pigeonpea growth (Hijmans et al. 2002). Similarly, elevation, minimum and maximum temperature at ICRISAT, Patancheru location during the crop season is close to that of low elevational zone (Fig. 2). Whiteman et al. (1985) reported that flowering of all maturity groups occurs sooner in moderate temperature of $22-30^{\circ} \mathrm{C}$, even under long days (12.5-16 h) and both low and high temperatures delay flowering in pigeonpea. 
Table 4 Frequency distribution (\%) for different modalities of various characters of pigeonpea germplasm collected from different elevations of Kenya

\begin{tabular}{|c|c|c|c|c|c|c|}
\hline \multirow[t]{2}{*}{ Character } & \multicolumn{2}{|c|}{ Extreme group } & \multicolumn{4}{|c|}{ Elevation (m.a.s.l.) } \\
\hline & & & $\begin{array}{l}\text { Low } \\
(<500)\end{array}$ & $\begin{array}{l}\text { Medium } \\
(500-1000)\end{array}$ & $\begin{array}{l}\text { High } \\
(1000-1500)\end{array}$ & $\begin{array}{l}\text { Very high } \\
(>1500)\end{array}$ \\
\hline \multirow[t]{2}{*}{ Days to $50 \%$ flowering } & Early & $(<130)$ & 23.81 & 1.47 & 0.56 & 0.00 \\
\hline & Late & $(>160)$ & 19.05 & 77.94 & 93.22 & 100.00 \\
\hline \multirow[t]{2}{*}{ Days to $75 \%$ maturity } & Early & $(<180)$ & 21.43 & 1.47 & 0.56 & 0.00 \\
\hline & Late & $(>225)$ & 28.57 & 82.35 & 92.09 & 100.00 \\
\hline \multirow[t]{2}{*}{ Plant height $(\mathrm{cm})$} & Short & $(<130)$ & 21.43 & 2.94 & 4.52 & 0.00 \\
\hline & Tall & $(>225)$ & 26.19 & 39.71 & 42.37 & 69.57 \\
\hline \multirow[t]{2}{*}{ Primary branches per plant (no.) } & Low & $(<5)$ & 9.52 & 11.76 & 20.34 & 8.70 \\
\hline & High & $(>10)$ & 50.00 & 26.47 & 19.21 & 26.09 \\
\hline \multirow[t]{2}{*}{ Secondary branches per plant (no.) } & Low & $(<15)$ & 35.71 & 45.59 & 56.50 & 39.13 \\
\hline & High & $(>25)$ & 23.81 & 19.12 & 8.47 & 17.39 \\
\hline \multirow[t]{2}{*}{ Tertiary branches per plant (no.) } & Low & $(<5)$ & 69.05 & 67.65 & 68.36 & 47.83 \\
\hline & High & $(>10)$ & 7.14 & 11.76 & 10.17 & 17.39 \\
\hline \multirow[t]{2}{*}{ Racemes per plant (no.) } & Low & $(<30)$ & 19.05 & 16.18 & 42.37 & 21.74 \\
\hline & High & $(>150)$ & 2.38 & 5.88 & 1.69 & 0.00 \\
\hline \multirow[t]{2}{*}{ Pod bearing length $(\mathrm{cm})$} & Short & $(<20)$ & 23.81 & 41.18 & 51.98 & 73.91 \\
\hline & Long & $(>40)$ & 14.29 & 14.71 & 11.30 & 0.00 \\
\hline \multirow[t]{2}{*}{ Pod length $(\mathrm{cm})$} & Small & $(<6)$ & 2.38 & 4.41 & 2.82 & 8.70 \\
\hline & Long & $(>10)$ & 11.90 & 1.47 & 0.56 & 0.00 \\
\hline \multirow{2}{*}{ Pods per plant (no.) } & Low & $(<100)$ & 42.86 & 69.12 & 87.01 & 95.65 \\
\hline & High & $(>250)$ & 7.14 & 5.88 & 2.82 & 0.00 \\
\hline \multirow[t]{2}{*}{ Seeds per pod (no.) } & Low & $(<4)$ & 11.90 & 13.24 & 8.47 & 4.35 \\
\hline & High & $(>5)$ & 57.14 & 19.12 & 27.12 & 8.70 \\
\hline \multirow[t]{2}{*}{100 seed weight $(\mathrm{g})$} & Small & $(<10)$ & 30.95 & 2.94 & 3.39 & 4.35 \\
\hline & Large & $(>15)$ & 4.76 & 38.24 & 53.67 & 65.22 \\
\hline \multirow[t]{2}{*}{ Shelling percentage } & Low & $(<20)$ & 2.38 & 1.47 & 1.13 & 0.00 \\
\hline & High & $(>60)$ & 16.67 & 23.53 & 19.77 & 43.48 \\
\hline \multirow[t]{2}{*}{ Seed yield per plant $(\mathrm{g})$} & Low & $(<20)$ & 30.95 & 51.47 & 70.06 & 60.87 \\
\hline & High & $(>100)$ & 7.14 & 0.00 & 0.56 & 0.00 \\
\hline \multirow[t]{2}{*}{ Harvest index (\%) } & Low & $(<10)$ & 26.19 & 51.47 & 69.49 & 82.61 \\
\hline & High & $(>20)$ & 11.90 & 5.88 & 2.82 & 0.00 \\
\hline \multirow[t]{2}{*}{ Protein content $(\%)$} & Low & $(<18)$ & 11.90 & 10.29 & 6.78 & 13.04 \\
\hline & High & $(>20)$ & 38.10 & 41.18 & 45.76 & 60.87 \\
\hline
\end{tabular}

A high frequency of accessions (21.4\%) from the low elevation zone was short (less than $130 \mathrm{~cm}$ ), while $69.6 \%$ accessions from very high elevation zone grew tall (more than $225 \mathrm{~cm}$ ) (Table 4). Generally, the frequency of short height accessions decreased and that of tall accessions increased with the elevation. None of the accessions from very high elevation zone were short. Plant height is related to maturity duration, photoperiod, temperature sensitivity and environment. Because of their prolonged vegetative growth, long duration pigeonpeas adapted to higher elevations grow tall (Remananadan 1990).

The low elevation zone was the best source of accessions with high number of primary and secondary branches, long pods, high number of pods per plant and seeds per pod, seed yield and harvest index. The medium elevation zone was the best source of accessions with a high raceme number and high pod bearing length. The very high elevation zone was the best source of accessions that produce more tertiary branches, large seeds, a high shelling percentage and a high seed protein content. Pigeonpea accessions from very high elevation are good sources for breeding vegetable types, because of their very large seed size.

The frequency of accessions with longer pod bearing branches, long pods, more pods per plant and more seeds per pod, a high seed yield and a high harvest index decreased with the increase in elevation, suggesting that the accessions from the 


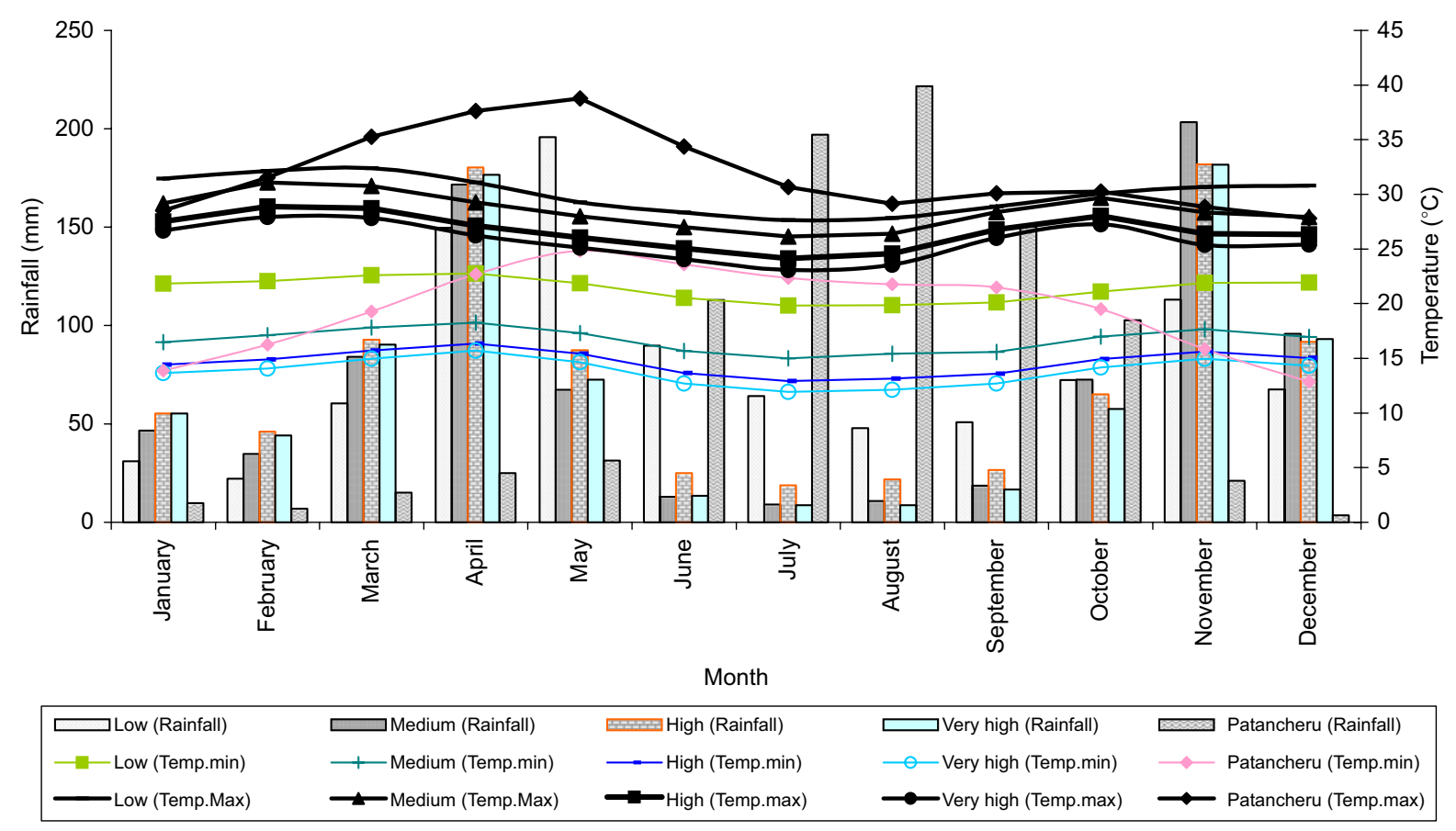

Fig. 2 Monthly mean minimum and maximum temperature and total rainfall at pigeonpea germplasm collection sites in Kenya and evaluation site at Patancheru, India

low elevation zone are the most promising for improving the yield components and yield. The differential behavior of accessions collected from varying elevations for different characters could be attributed largely to the temperature determined by the elevations (Gupta et al. 1991).

The results of our study imply that elevation of collection sites is an important determinant of variation patterns in a range of traits of pigeonpea in Kenya. Therefore, it is very essential to collect accurate and complete passport information, particularly on latitude, longitude, elevation, temperature and rainfall, to maximize the value of collected germplasm. This information will be very useful in predicting the genetic characteristics of the collected germplasm. Natural selection pressure for adaptation to different elevations, coupled with farmers' selection over many years at varying elevations also accounted for the observed diversity pattern. Though, the evaluation data used in the present study are preliminary in nature, these data reflect the differences in the genetic makeup of the accessions in terms of clear patterns of diversity. Further testing of trait specific germplasm at or near the place of origin will provide an opportunity to identify accessions with high potential for utilization in pigeonpea improvement.

\section{References}

Food and Agriculture Organization (2005) http://www/ FAO.ORG/FAOSTAT database

Gooding HJ (1962) The agronomic aspects of pigeonpeas. Field Crop Abstracts 15:1-5

Gupta SC, Singh L, Ariyanayagam RP (1991) Adaptation of short-duration pigeonpea to higher latitudes and altitudes. Int Pigeonpea Newslett 13, Feb 1991

Hayward MD, Breese EL (1993) Population structure and variability. In: Hayward MD, Bosemark NO, Romagosa I (eds) Plant breeding principles and prospects. Chapman \& Hall, London, pp 16-29

Hijmans RJ, Gaurino L, Rajas E (2002) Diva-GIS. Version 2. A geographic information system for analysis of biodiversity data. Manual. International Potato Center, Lima, Peru

IBPGR and ICRISAT (1993) Descriptors for Pigeonpea [Cajanus cajan (L.) Millsp.]. International Board for Plant Genetic Resources, Rome, Italy. International Crops Research Institute for the Semi-Arid Tropics, Patancheru, India

ICRISAT (International Crops Research Institute for the Semi-Arid Tropics) (1978) Annual Report 1977/78. Patancheru, AP 502 324, India, ICRISAT, p 295 
Keuls M (1952) The use of the "Studentized range" in connection with an analysis of variance. Euphytica $1: 112-122$

Levene H (1960) Robust tests for equality of variances. In: Oklin I (ed) Contributions to probability and statistics. Essays in honor of Harold Hotelling. Stanford University Press, Stanford, pp 278-292

Newman D (1939) The distribution of range in samples from a normal population expressed in terms of an independent estimate of standard deviation. Biometrika 31:20-30

Ong CK, Monteith JL (1985) Response of pearl millet to light and temperature. Field Crops Res 11:141-160

Remanandan P (1990) Pigeonpea: genetic resources. In: Nene YL, Hall SD, Shiela VK (eds) The pigeonpea. CAB International, Wallingford, Oxon OX 10 8DE, UK, pp 89-115

Remanandan P, Omanga PGA, Shakoor A, Mengesha MH, Sastry DVSSR (1991) Regional pigeonpea germplasm evaluation in Kenya. In: Singh L, Silim SN, Ariyanayagam RP, Reddy MV (eds). Proceedings of the first Eastern and Southern Africa Regional Legumes (Pigeonpea) workshop, 25-27 Jun 1990, Nairobi, Kenya. PO Box 39063, Nairobi, Kenya:
Eastern Africa Regional Cereals and Legumes (EARCAL) Program, International Crops Research Institute for the Semi-Arid Tropics

Remanandan P, Shakoor A, Ngugi ECK (1982) Pigeonpea germplam collection mission in Kenya. Genetic Resources Progress Report No. 48, ICRISAT, Patancheru, India

Shannon CE, Weaver W (1949) The mathematical theory of communication. Univ. Illinois Press, Urbana

Singh U, Jambunathan R (1980) Evaluation of rapid methods for estimation of protein in chickpea (Cicer arietinum (L.). J Sci Food Agric 31:247-254

Spence JA, Williams SJA (1972) Use of photoperiod response to change plant design. Crop Sci 12:121-122

van der Maesen LJG (1976) Pigeonpea collection trip in Kenya. Genetic Resources Progress Report, ICRISAT, Patancheru

Whiteman PC, Byth DE, Wallis ES (1985) Pigeonpea [Cajanus cajan (L.) Millisp.]. In: Summerfield RJ, Roberts EH (eds) Grain legume crops. Collins Professional and Technical Books, London, pp 685698 